\title{
Pengembangan Modul Pembelajaran Bilangan Berbasis Tematik Saintifik
}

\author{
I Ketut Suastika \\ Universitas Kanjuruhan Malang \\ suastika@unikama.ac.id
}

\begin{abstract}
Abstrak
Fokus penelitian ini adalah mengembangkan produk yang berupa modul pembelajaran bilangan berbasis tematik saintifik yang memenuhi kriteria valid, praktis, dan efektif. Metode pengembangan pada penelitian ini adalah development study dengan tahapan penelitian mengikuti Plomp (2007) yaitu: (1) Preliminary research, (2) Prototyping stage, (3) Summative evaluation. Kevalidan modul ditinjau dari isi dan konstruknya. Kevalidan modul ini ditentukan oleh validator. Modul yang sudah dinyatakan valid, kemudian dilakukan ujicoba di kelas untuk menentukan kepraktisan dan keefektifannya. Kepraktisan modul ditinjau dari hasil pengamatan tentang keterlaksanaan modul, sedangkan keefektifannya ditinjau dari penguasaan bahan ajar, dan respon peserta didik terhadap modul. Hasil ujicoba menunjukkan bahwa modul yang dikembangkan memenuhi kriteria kepraktisan dan keefektifan.

Kata Kunci: Pengembangan, modul, tematik saintifik
\end{abstract}

\section{PENDAHULUAN}

Mulai tahun pelajaran 2014 pembelajaran di Sekolah Dasar telah diterapkan pembelajaran tematik terpadu. Sementara, berbagai kendala muncul di sana, antara lain: (1) para guru cenderung belum siap untuk merubah kebiasaan lama yang cenderung mengajar per bidang studi, (2) perlu adanya persiapan yang matang dan kreatifitas tinggi agar pembelajaran tematik terpadu dapat terjadi secara alami, (3) kurangnya sumber belajar alternatif yang memadai untuk mendukung proses pembelajaran yang diharapkan. Oleh karena itu, perlu adanya pembenahan - pembenahan antara lain dalam hal:
(1) pelaksana pembelajaran, perangkat pendukung pembelajaran. Pembenahan pelaksana pembelajaran dalam arti peningkatan kompetensi pedagogik guru sebagai pelaksana utama dalam proses pembelajaran. Pembenahan ini bisa dilakukan melalui penataran dan diklat bagi guru-guru (In-service) dan pembenahan kurikulum serta proses pembelajaran di lembaga pencetak calon guru (pre-service). Pembenahan perangkat pendukung pembelajaran, antara lain, perlunya dikembangkan, buku sumber, media dan sistem interaksi yang mendukung pembelajaran tematik terpadu. 
Proses pembelajaran pada Kurikulum 2013 untuk semua jenjang menuntut dilaksanakan dengan menggunakan pendekatan ilmiah. Proses pembelajaran harus menyentuh tiga ranah, yaitu sikap, pengetahuan, dan keterampilan. Dalam proses pembelajaran berbasis pendekatan ilmiah, ranah sikap menggamit transformasi substansi atau materi ajar agar peserta didik tahu tentang 'mengapa'. Ranah keterampilan menggamit transformasi substansi atau materi ajar agar peserta didik tahu tentang 'bagaimana'. Ranah pengetahuan menggamit transformasi substansi atau materi ajar agar peserta didik tahu tentang 'apa'.Hasil akhirnya adalah peningkatan dan keseimbangan antara kemampuan untuk menjadi manusia yang baik (soft skills) dan manusia yang memiliki kecakapan dan pengetahuan untuk hidup secara layak (hard skills) dari peserta didik yang meliputi aspek kompetensi sikap, keterampilan, dan pengetahuan. Perubahan pada proses pembelajaran yang dimaksudkan di atas mencakup: a) berorientasi pada karakteristik kompetensi yag mencakup: 1) sikap: menerima, menjalankan, menghargai, menghayati, dan mengamalkan, 2) keterampilan: mengamati, menanya, mencoba, menalar, menyajikan, dan mencipta, dan 3) pengetahuan: mengetahui, memahami, menerapkan, menganalisis, mengevaluasi, dan mencipta; b) menggunakan pendekatan saintifik, karakteristik kompetensi sesuai jenjang.

Dari hasil pengamatan diperoleh bahwa belum tersedianya buku pembelajaran matematika yang menunjang pembelajaran bilangan berbasis tematik-saintifik. Proses pembelajaran yang melibatkan pembelajaran matematika untuk mempersiapkan mahasiswa sebagai guru di sekolah dasar cenderung masih menggunakan metode konvensional yang belum menerapkan metode tematik maupun langkah-langkah pembelajaran saintifik; (2) Hasil wawancara dengan beberapa mahasiswa program studi PGSD Universitas Kanjuruhan Malang berkenaan dengan pemahamanya tentang pembelajaran tematik dan pembelajaran dengan pendekatan saintifik, rata-rata mereka masih kurang dalam pembelajaran tematiksaintifik; (3) Kondisi guru di lapangan dalam melaksanakan 
kegiatan belajar mengajar matematika, ditinjau dari persiapannya, pelaksanaannya, penilaiannya atau perilaku guru dalam pembelajaran tematik berbasis Saintifik, rata-rata mereka masih kurang paham dengan pembelajaran tematik-saintifik.

Program studi Pendidikan Guru Sekolah Dasar adalah salah satu lembaga yang dipercaya untuk mencetak calon guru yang dipersiapkan untuk menjadi pendidik di Sekolah Dasar. Oleh karena itu, secara pisik dan psikis perlu dipersiapkan untuk siap melaksanakan proses pembelajaran tematik terpadu di sekolah. Salah satu penunjang adalah perlu adanya sumber belajar yang mengarah pada proses pembelajaran tematik terpadu.

Salah satu upaya agar permasalahan pembelajaran di atas dapat teratasi, maka perlu dibuat bahan belajar alternatif bercirikan tematik terpadu yang berusaha membangun kompetensi mahasiswa PGSD sebagai calon guru. Salah satu alternatif tersebut adalah pembelajaran dengan modul. Dengan modul peserta didik dibimbing melalui langkah-langkah yang sistematis, untuk membangun kemampuanya dalam memahami materi. Dengan menggunakan modul dalam pembelajaran, kebutuhan peserta didik secara individu dapat terlayani (Shofan, dkk., 2013).

$$
\text { Pembelajaran dengan modul }
$$
menurut Direktorat Jendral Peningkatan Mutu Pendidik dan Tenaga Kependidikan Nasional (2008) adalah pendekatan pembelajaran mandiri yang berfokuskan penguasaan kompetensi dari bahan kajian yang dipelajarai peserta didik dengan waktu tertentu sesuai dengan potensi dan kondisinya. Menurut Mbulu (2001), keuntungan yang diperoleh dari pembelajaran dengan penerapan modul adalah sebagai berikut: (1) Memberi feedback atau balikan yang segera dan terus menerus, (2) Dapat disesuaikan dengan kemampuan siswa secara individual dengan memberikan keluwesan tentang kecepatan mempelajarinya, bentuk maupun bahan pelajaran, (3) Memberikan secara khusus pengajaran remidial untuk membantu siswa dalam mengatasi kekurangannya, (4) Membuka kemungkinan untuk melakukan tes formatif.

Berdasarkan uraian di atas, maka dipandang perlu untuk 
mengembangkan modul berbasis pada program studi PGSD. tematik saintifik untuk peserta didik

\section{METODE PENELITIAN}

Metode pengembangan penelitian ini adalah development study dengan tahapan penelitian mengikuti tahapan yang dikemukakan Plomp (2007) dengan langkahlangkah yaitu: (1) Preliminary research (studi pendahuluan): analisis konteks dan masalah untuk pengembangan landasan kerangka konseptual melalui review literature, observasi lapangan dan atau melakukan penelitian pendahuluan; (2) Prototyping stage (tahap perancangan prototipe): merancang petunjuk desain, mengoptimalkan prototype melalui daur rancangan, evaluasi formatif dan revisi; (3) Summative evaluation (tahap evaluasi): evaluasi terhadap efektifitas pelaksanaan dan penggunaan prototype. Untuk melihat kualitas modul yang telah dikembangkan, digunakan penilaian kualitas produk dari Neeven (2007). Penilaian kualitas produk tersebut terkait dengan kevalidan, kepraktisan, dan keefektifan untuk modul yang telah dikembangkan. Kevalidan produk ditentukan oleh validator, sedangkan kepraktisan dan keefektifan produk dilihat ketika ujicoba produk di kelas kecil.

1. Kevalidan Produk

Kevalidan produk ditentukan oleh validator. Untuk menentukan kevalidan produk yang dikembangkan digunakan Lembar Validasi. Lembar validasi ini terdiri dari 3 (tiga) aspek, yaitu: (1) struktur modul, (2) organisasi penulisan materi, dan (3) bahasa. Validasi dilakukan oleh 2 (dua) validator. Validator pertama adalah pakar pendidikan matematika, validator ke dua seorang praktisi. Skor maksimal pada masing-masing pernyataan pada lembar validasi adalah 5 . Produk dikatakan valid jika mendapatkan rata-rata skor dari kedua validator minimal 3.

2. Kepraktisan Produk Kepraktisan produk dilihat ketika ujicoba produk di lapangan. Kepraktisan produk pada saat ujicoba dilihat dari keterlaksanaan modul dalam pembelajaran yang meliputi 
aktivitas pendidik dan aktivitas

peserta didik dalam pembelajaran. Keterlaksanaan modul dalam pembelajaran dinilai oleh observer dengan menggunakan Lembar Pengamatan Keterlaksanan Modul (LPKM). Skor maksimal untuk masingmasing pernyataan pada LPKM adalah 5. Modul itu dikatakan praktis, jika keterlaksanaan modul , $\bar{T}$, masuk dalam kategori "tinggi", yaitu $\bar{T} \geq 3$,.

3. Keefektifan Produk

Keefektifan modul diukur dari: (1) penguasaan bahan ajar peserta didik, dan (2) respon peserta didik. Untuk mengetahui penguasaan bahan ajar peserta didik digunakan tes. Hasil tes dikatakan kategori "baik" jika peserta didik mendapatkan skor di atas 70. Hal ini dikarenakan peserta didik yang diberikan pembelajaran dengan modul adalah mahasiswa PGSD.

Data respon peserta didik terhadap modul diperoleh dengan angket respon peserta didik yang mempunyai skala 1

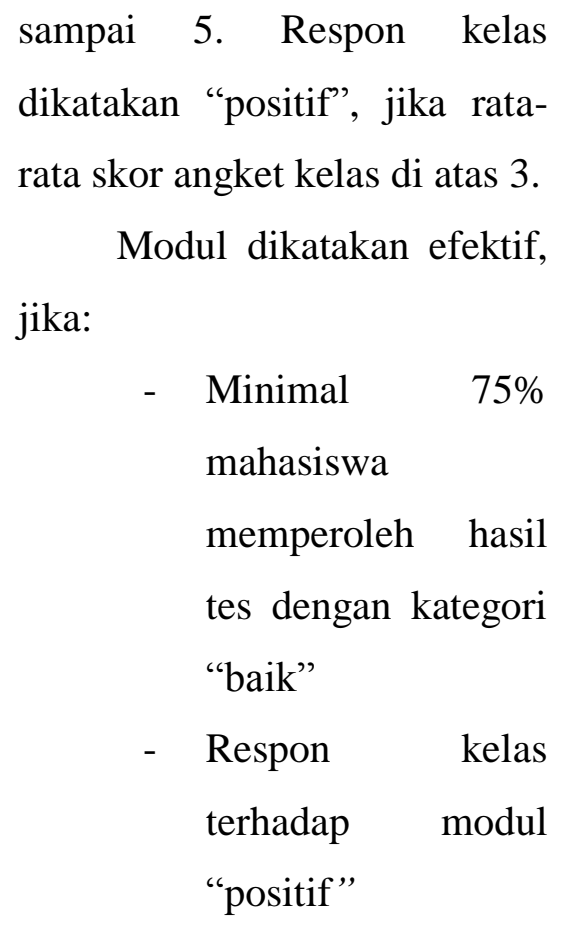
dikatakan "positif", jika ratarata skor angket kelas di atas 3 . Modul dikatakan efektif, jika:

- Minimal 75\% mahasiswa memperoleh hasil tes dengan kategori "baik" - Respon kelas terhadap modul "positif"

\section{HASIL PENELITIAN DAN PEMBAHASAN}

Hasil

Spesifikasi produk yang dikembangkan merupakan modul Pembelajaran Bilangan Berbasis Tematik-Saintifik yang memadukan materi-materi pembelajaran bilangan dikaitkan satu sama lain sebagai satu kesatuan membentuk pembelajaran inter-disipliner antar kompetensi dengan langkah-langkah pendekatan ilmiah. Komponen modul yang dikembangkan terdiri dari: (a) Tinjauan Mata Pelajaran. (b). Petunjuk Belajar (c). Pendahuluan, (d). Kegiatan Belajar, (e). Latihan (f). Rambu-rambu Jawaban latihan. 
(g). Rangkuman (h). Tes Formatif.

(i). Kunci Jawaban Tes Formatif. (j). Umpan Balik dan Tindak lanjut.

Bagian Pendahuluan berisi : 1)

Cakupan isi modul dalam bentuk deskripsi singkat.2) Indikator yang ingin dicapai 3) Deskripsi perilaku awal (entry behaviour) sebagai pijakan (anchoring) dari pembahasan modul itu. 4) Relevansi, 5) Urutan butir sajian modul (kegiatan belajar) secara logis, dan 6) Petunjuk belajar. Untuk bagian Kegiatan Belajar berisi pemaparan materi pelajaran.

Berikut disajikan hasil validasi dari validator dan hasil ujicoba modul di kelas. Untuk hasil validasi disajikan pada Tabel 1, untuk hasil ujicoba modul disajikan pada Tabel 2 dan Tabel 3.

Tabel 1. Rekapitulasi Hasil validasi

\begin{tabular}{|l|l|c|c|c|}
\hline No $\cdot$ & Aspek yang Dinilai & $\begin{array}{c}\text { Rata-rata } \\
\text { skor } \\
\text { validator I }\end{array}$ & $\begin{array}{c}\text { Rata-rata } \\
\text { skor } \\
\text { validator II }\end{array}$ & Rata-rata \\
\hline 1 & Struktur Modul & 4,0 & 3,6 & 3,8 \\
\hline 2 & Organisasi Penulisan Materi & 4,5 & 4,3 & 4,4 \\
\hline 3 & Bahasa & 4,0 & 3,3 & 3,7 \\
\hline \multicolumn{2}{|c|}{ Rata-Rata } & & $\mathbf{3 , 9 7}$ \\
\hline
\end{tabular}

Tabel 2. Rekapitulasi Hasil Keterlaksanaan Modul

\begin{tabular}{|c|l|c|c|c|c|}
\hline \multirow{2}{*}{ No. } & \multicolumn{1}{|c|}{ Kompetensi Dasar } & \multicolumn{4}{|c|}{ Keterlaksanaan Modul } \\
\cline { 3 - 6 } & $\begin{array}{c}\text { Aktivitas } \\
\text { Pendidik }\end{array}$ & Kategori & $\begin{array}{c}\text { Aktivitas } \\
\text { Peserta Didik }\end{array}$ & Kategori \\
\hline 1 & $\begin{array}{l}\text { Mengajarkan pengenalan } \\
\text { bilangan Asli dan bilangan } \\
\text { bulat }\end{array}$ & 3,9 & Tinggi & 3,7 & Tinggi \\
\hline 2 & $\begin{array}{l}\text { Mengajarkan pengenalan } \\
\text { bilangan Rasional }\end{array}$ & 3,9 & Tinggi & 3,9 & Tinggi \\
\hline 3 & $\begin{array}{l}\text { Mengajarkan bilangan } \\
\text { kardinal dan bilangan ordinal }\end{array}$ & 3,7 & Tinggi & 3,8 & Tinggi \\
\hline 4 & $\begin{array}{l}\text { Mengajarkan konsep habis } \\
\text { dibagi }\end{array}$ & 3,7 & Tinggi & 3,7 & Tinggi \\
\hline 5 & Mengajarkan FPB dan KPK & 3,7 & Tinggi & 3,8 & Tinggi \\
\hline \multicolumn{1}{|c|}{ Rata-rata } & $\mathbf{3 , 7 8}$ & Tinggi & $\mathbf{3 , 7 8}$ & Tinggi \\
\hline
\end{tabular}

Tabel 3. Rekapitulasi Hasil Angket Terhadap Modul

\begin{tabular}{|l|l|c|c|}
\hline No & \multicolumn{1}{|c|}{ Aspek yang Dinilai } & $\begin{array}{c}\text { Rata- } \\
\text { Rata Skor }\end{array}$ & \multicolumn{1}{|c|}{ Ket } \\
\hline $\mathbf{1}$ & $\begin{array}{l}\text { Penyajian modul membuat saya tertarik untuk } \\
\text { membacanya }\end{array}$ & 3,25 & Positif \\
\hline
\end{tabular}




\begin{tabular}{|l|l|c|c|}
\hline $\mathbf{2}$ & $\begin{array}{l}\text { Penyajian modul dilengkapi dengan gambar dan } \\
\text { tabel }\end{array}$ & 4,25 & Positif \\
\hline $\mathbf{3}$ & $\begin{array}{l}\text { Penyajian modul dilengkapi dengan rangkuman } \\
\text { materi }\end{array}$ & 3,75 & Positif \\
\hline $\mathbf{4}$ & Penyajian modul dilengkapi dengan glosarium & 3,27 & Positif \\
\hline $\mathbf{5}$ & Penyajian modul dilengkapi dengan daftar pustaka & 4,05 & Positif \\
\hline $\mathbf{6}$ & $\begin{array}{l}\text { Cakupan materi yang ada dalam modul jelas dan } \\
\text { runtut sehingga mudah saya pahami }\end{array}$ & 4.05 & Positif \\
\hline $\mathbf{7}$ & $\begin{array}{l}\text { Masalah yang disajikan dalam materi modul, sesuai } \\
\text { dengan kehidupan sehari-hari saya }\end{array}$ & 4.50 & Positif \\
\hline $\mathbf{8}$ & $\begin{array}{l}\text { Saya merasa senang jika pembelajaran menggunakan } \\
\text { modul ini }\end{array}$ & 4.05 & Positif \\
\hline $\mathbf{9}$ & $\begin{array}{l}\text { Penggunaan modul dalam kegiatan pembelajaran } \\
\text { lebih mudah untuk saya pahami }\end{array}$ & 4.25 & Positif \\
\hline $\mathbf{1 0}$ & Bahasa yang digunakan dalam modul sesuai EYD & 3.70 & Positif \\
\hline $\mathbf{1 1}$ & $\begin{array}{l}\text { Bahasa yang digunakan dalam modul komunikatif } \\
\text { dan mudah saya pahami }\end{array}$ & 4,00 & Positif \\
\hline $\mathbf{1 2}$ & $\begin{array}{l}\text { Struktur kalimat yang digunakan dalam modul jelas } \\
\text { dan sederhana }\end{array}$ & 3,95 & Positif \\
\hline & \multicolumn{2}{|l|}{ Rata-Rata } & Positif \\
\hline
\end{tabular}

Untuk hasil tes penguasaan bahan ajar, terdapat 31 dari 34 orang peserta didik (91 $\%$ ) memperoleh skor di atas 70, dengan rata-rata hasil tes peserta didik adalah 80,65.

\section{Pembahasan}

Pada pembahasan ini difokuskan pada dua hal, yaitu: (1) validasi modul, (2) hasil ujicoba modul. Validasi modul dilakukan oleh dua orang validator, yaitu seorang ahli dan seorang praktisi. Hasil analisis validasi menunjukkan bahwa modul pembelajarannya termasuk pada kategori valid dan layak untuk digunakan.

Ujicoba modul dilakukan dalam rangka melihat kepraktisan dan keefektifan modul. ujicoba dilakukan pada mahasiswa program studi PGSD
Universitas Kanjuruhan Malang yang menempuh matakuliah Pembelajaran Bilangan. Ujicoba dilakukan 5 (lima) kali pertemuan. Rata-rata keseluruhan masing-masing aspek untuk keterlaksanaan modul baik itu pendidik maupun peserta didik pada masing-masing pertemuan masuk pada kategori "tinggi”, maka dapat disimpulkan bahwa modul praktis untuk digunakan. Keefektifan modul diukur dari 2 (dua) indikator, yaitu: penguasaan bahan ajar, dan respon peserta didik. Rata-rata penguasaan bahan ajar dari 34 peserta didik 
adalah 80,65, dengan $91 \%$ peserta didik masuk kategori "baik", sedangkan respon peserta didik pada modul masuk pada kategori "tinggi". Hasil wawancara terhadap beberapa peserta didik saat selesai pembelajaran dengan modul, sebagian besar mereka menyatakan senang belajar dengan modul. Oleh karena itu dapat dikatakan bahwa Modul Pembelajaran Bilangan Berbasis Tematik-Saintifik Bagi Mahasiswa PGSD efektif digunakan.

Hasil peneltian ini sesuai dengan hasil penelitian: (1) Aditia, dkk (2013) bahwa siswa merespon secara positif terhadap penggunaan modul pada pembelajaran;

Nilasari, dkk. (2016) bahwa penggunaan modul pembelajaran memberikan pengaruh terhadap hasil belajar siswa; (3) Nurnaini (2013) bahwa penggunaan modul dapat membuat peserta didik sangat mudah memahami materi, dan tidak tergantung pada guru.

\section{KESIMPULAN}

Modul pembelajaran bilangan berbasis tematik saintifik yang dikembangkan ini memenuhi kriteria kevalidan, kepraktisan, dan keefektifan. Pengembangan modul ini mengikuti tahapan pengembangan Plomp (2007). Belajar dengan menggunakan Modul pembelajaran bilangan berbasis tematik saintifik dapat mempengaruhi hasil belajar mahasiswa.

\section{DAFTAR PUSTAKA}

Aditia, M.T.\& Muspiroh, N. (2013). Pengembangan Modul Pembeljaran Berbasis Sains, Lingkungan, Teknologi, Masyarakat dan Islam (Salingtematis) dalam Meningkatkan Hasil Belajar Siswa Pada Konsep Ekosistem Kelas X di SMA NU Lemahabang Kabupaten Cirebon. Jurnal Scientiae Educatia, Vol 2. Edisi 2. 2013.

Badan Pengembangan Sumber Daya Manusia Pendidikan dan Kebudayaan dan Penjaminan Mutu Pendidikan Kementerian Pendidikan dan Kebudayaan. (2013). Materi Pelatihan Guru Implementasi Kurikulum 2013: Matematika SMP/MTs. Jakarta:

Kemendikbud

Direktorat Jendral Peningkatan Mutu Pendidik dan Tenaga Kependidikan Nasional. (2008). Penulisan Modul. Jakarta: Departemen Pendidikan Nasional 
Mbulu, J. (2001). Pengajaran Individual. Malang. Yayasan Elang Emas.

Neeveen., N., Folmer, E. (2007). Educational Design Research. Dalam Plomp, T.\&Neeven, N. (Eds), Formative Evaluation in Educational Design Research. Proceedings of the seminar conducted at the East China Normal University, Shanghai (PR China), November 23 26, 2007.

Nilasari, E, Djatmika, E.T., dan Santoso, A. (2016). Pengaruh Penggunaan Modul Pembelajaran Kontekstual Terhadap Hasil Belajar Siswa Kelas V Sekolah Dasar. Jurnal Pendidikan. Vol 1. No. 7 . halaman 1399-1404

Nurnaini, A. (2013). Pengaruh Media Pembelajaran Modul Terhadap Pencapaian Kompetensi Membuat Pola Dasar di SMKN 4 Yogyakarta. (Online) Tersedia di eprints.uny.ac.id/10369/1/Jurna I.pdf

Permendikbud no 65 tahun 2013 tentang Standar Proses Pendidikan Dasar dan Menengah.

Plomp, T. 2007. Educational Design Research. Dalam Plomp, T.\&Neeven, N. (Eds), Educational Design Research: An Introduction. Proceedings of the seminar conducted at the East China Normal University, Shanghai (PR China), November 23 - 26, 2007.

Shofan, M., Sa'dijah., dan Slamet. (2013). Pengembangan Modul Pembelajaran Bilangan Bulat Dengan Pendekatan Kontekstual untuk Siswa Kelas IV SD/MI (online). Tersedia di jurnalonline.um.ac.id/data /.../artikelF98AOF2A4C247D 519F011A66CF2F1F22.pdf 